\title{
Influence of Environmental Factors and Cultural Methods on the Content of $N, N$-Dimethyltryptamine in Psychotria viridis (Rubiaceae)
}

\author{
André D. Cavalcante, ${ }^{*}, a$ Gabriele A. Cardoso, ${ }^{b}$ Fernando L. P. de Oliveira, ${ }^{c}$ \\ Eduardo Bearzoti, ${ }^{c}$ Adriana A. Okuma, ${ }^{d}$ Lucienir P. Duarte ${ }^{e}$ and Sidney A. Vieira-Filho ${ }^{f}$ \\ ${ }^{a}$ Setor-Técnico Científico da Polícia Federal do Brasil, \\ Rua Nascimento Gurgel, 30, 30441-170 Belo Horizonte-MG, Brazil \\ ${ }^{b}$ Programa de Pós-Graduação em Química, Universidade Federal dos Vales do Jequitinhonha e Mucuri, \\ Campus JK, 39100-000 Diamantina-MG, Brazil \\ 'Departamento de Estatística, Universidade Federal de Ouro Preto, \\ Campus Morro do Cruzeiro, s/n, 35400-000 Ouro Preto-MG, Brazil \\ ${ }^{d}$ Departamento de Química, Centro Federal de Educação Tecnológica de Minas Gerais, \\ Av. Amazonas, 5253, 30421-169 Belo Horizonte-MG, Brazil \\ ${ }^{e}$ Departamento de Química, Universidade Federal de Minas Gerais, \\ Av. Antonio Carlos, 6627, Pampulha, 31270-901 Belo Horizonte-MG, Brazil \\ ${ }^{f}$ Departamento de Farmácia, Universidade Federal de Ouro Preto, \\ Campus Morro do Cruzeiro, s/n, 35400-000 Ouro Preto-MG, Brazil
}

\begin{abstract}
Psychotria viridis is one of the species that produces $N, N$-dimethyltryptamine. Its decoction together with other species, such as Banisteriopsis caapi, produces ayahuasca, a beverage used for ritualistic and medicinal purposes. The goal of this study was to understand how environmental factors and cultivation methods influenced the content of $N, N$-dimethyltryptamine in $P$. viridis. Over all four seasons, leaf samples were collected from 25 different locations in 14 Brazilian states, and Federal District. Environmental parameters, micro and macronutrients, plant characteristics, information on farming methods were correlated with $N, N$-dimethyltryptamine content, determined by gas chromatography coupled to mass spectrometry (GC-MS). Greatest effects on the $N, N$-dimethyltryptamine amount were associated with seasonality, altitude, latitude and biome type. A positive correlation between $\mathrm{N}$ and $\mathrm{Mg}$ content and $\mathrm{N}, \mathrm{N}$-dimethyltryptamine levels was statistically established. By regression analysis, the adequate foliar nutrient levels that would result in the concentration of $N, N$-dimethyltryptamine in cultivated plants similar to that of Amazonian $P$. viridis were equated.
\end{abstract}

Keywords: chacrona, ayahuasca, secondary metabolite, DMT

\section{Introduction}

Ayahuasca is a beverage currently used by over 70 different indigenous groups, distributed in Brazil, Bolivia, Colombia, Ecuador, Peru, and Venezuela. ${ }^{1}$ The origin of its use has been lost in time, but dates back thousands of years. The oldest evidence dating back to 1500-2000 before Christ is represented by ceramic vessels supposedly used to ingest the beverage. ${ }^{2}$ Ayahuasca, known in Brazil as "daime", "hoasca", or "vegetal", is a beverage that

*e-mail: andre.adc@dpf.gov.br has been incorporated in religious rituals by several syncretic religious groups in Brazil, such as "União do Vegetal" (UDV), "Santo Daime", and "Barquinha". ${ }^{2}$ At the beginning of this study, the UDV had approximately 160 sites with extensive cultivation of $P$. viridis spread throughout Brazil. The UDV cultivates the plants on land that the church owns and maintains exclusively for religious purposes to prepare the ayahuasca beverage. The use of ayahuasca was approved by the Brazilian Government through Resolution No. 1 of January 25, 2010 of the Conselho Nacional de Políticas sobre Drogas (CONAD). ${ }^{3}$ 
In general, ayahuasca is prepared by a decoction of two plants, a liana classified as Banisteriopsis caapi (Malpighiaceae), which is popularly known in Brazil as "mariri" or "jagube", along with a shrub Psychotria viridis (Rubiaceae), commonly known as "chacrona". The principal psychoactive constituents of B. caapi are harmine, harmaline, and tetrahydroharmine, and of $P$. viridis is $\mathrm{N}, \mathrm{N}$-dimethyltryptamine (DMT). DMT is a psychoactive $5-\mathrm{HT}_{2 \mathrm{~A}}$ agonist that causes an intense effect characterized by symptoms similar to those produced by lysergic acid diethylamide (LSD). ${ }^{4}$ However, at doses used in religious rituals, the psychological effects induced by the DMT content in the beverage are less intense than those of preparations consisting exclusively of injected, smoked or insufflated DMT. ${ }^{5}$ P. viridis (Figure S1, Supplementary Information (SI) section) is native to the Amazon region, but in recent decades it has become widely cultivated in different regions and biomes of Brazil.

The process of domestication and large-scale cultivation of $P$. viridis in different Brazilian ecosystems induces the plant to adapt to very different conditions from their original environment. Although being from an original environment of tropical forest characterized by hot, humid, and predominantly low altitudes, $P$. viridis is currently grown in semi-arid climates that have prolonged dry periods that can last for years and in mountainous regions with altitudes of approximately $1000 \mathrm{~m}$ and lower temperatures than those found in the Amazon region. These differences may interfere with the concentration of secondary metabolites.

Secondary metabolites play an important role in plant adaptation to environmental conditions and overcoming various types of stress. ${ }^{6-8}$ The concentration of chemical constituents in plants depends on the stimuli generated by the environment, which induces the biosynthesis of several secondary metabolites according to ecological relationships of the plants. ${ }^{9}$ Factors such as the stage of development, the season of harvest, time of day, availability of essential metals, water stress, and others, influence the production of secondary metabolite such as alkaloids, terpenes, and others. ${ }^{10}$ The availability of essential metals in soil represents one of the main factors that affects the secondary metabolism of plants. ${ }^{11,12}$ As example, phosphorus is necessary for the biosynthesis of nucleic acids, structural constituents of cell membranes, and the production of adenosine triphosphate (ATP). Potassium and calcium are involved in the activity of several enzymes and in the vegetable cell membrane integrity. ${ }^{11}$ Manganese and zinc participate in different stages of the biosynthesis of chlorophyll, and copper and boron are essential for the synthesis of plant hormones, translocation of carbohydrates, and nucleic acid formation. ${ }^{11}$ Magnesium is essential for the process of photosynthesis, and it participates in the formation of ATP, protein synthesis, and loading of nutrients through the phloem. ${ }^{12}$ Nitrogen and sulfur play important roles in the formation of amino acids, proteins and production of nitrogenated compounds in plants. Thus, variation in the concentration of compounds such as alkaloids, can be in part correlated to differences in leaf nitrogen content. ${ }^{13}$

Based on the fact that agricultural practices, environmental and other factors influence the plant metabolism, in the present study these parameters, together with the determination of $\mathrm{N}, \mathrm{P}, \mathrm{K}, \mathrm{Ca}, \mathrm{Mg}, \mathrm{S}, \mathrm{B}, \mathrm{Mn}, \mathrm{Cu}$, and $\mathrm{Zn}$ in soil and leaves, were correlated with the DMT content in leaves of $P$. viridis.

The effects of environmental parameters (altitude, latitude, rainfall and seasonality), plant characteristics (foliar nutrients, pest infestation, flowering period, and vitality), and planting methods (use of irrigation and correction of soil acidity) on DMT content in the P. viridis leaves were also determined. Regression analysis was used to establish equations to calculate the adequate foliar nutrient (supplementation) levels that would result in the concentration of DMT in cultivated plants that was similar to that of Amazonian P. viridis.

\section{Experimental}

\section{Plant material}

The leaves of $P$. viridis used in the chemical analysis were kindly provided by the "União do Vegetal" (UDV), Brazil. Samples were collected at 25 sites of UDV, located in 14 states and in the Federal District of Brazil. These sites were distributed in the following biomes: Amazon forest, Atlantic forest, Caatinga (a typical Brazilian semi-desert area with an ecoregion characterized by this vegetation), and Cerrado (a vast tropical savanna). The samples were collected in April 2013, July 2013, October 2013, and January 2014, covering all four seasons. Only healthy leaves were collected. Leaves were collected from 7:30 am to 8:30 am from 20 plants selected by following a zig-zag scheme on the ground. Leaves were sampled only in the middle third of the height of $P$. viridis. On the scheduled date, three pairs of leaves were collected from each plant; represented by six sheets at each specimen, totaling 120 sheets in each sampling period. Only leaves located in the $3^{\text {rd }}$ and $4^{\text {th }}$ pair of leaves, counted from the end of the $P$. viridis branch, were collected. After collection, the leaves were placed in a white paper envelope with small holes and without printed inscriptions. The envelopes were packed in cardboard boxes. On the same day of collection, the 
samples were sent to the laboratory of the Federal Police, located in the state of Minas Gerais, Brazil, by an express mail service (SEDEX). Thus, the material was received by this laboratory within two days after collection. To evaluate the variation in DMT within a given UDV site at the same collection location, it was made specific evaluations of DMT. Thus, in 10 UDV sites, samples (10 leaves) were collected from 10 specimens of $P$. viridis, totaling 100 samples at the end of the sampling period.

\section{Selection sites for sampling}

After contacting approximately 160 sites with $P$. viridis plantations through the UDV, 80 sites expressed their interest in participating in this study, and agreed to provide samples of leaves and information about farming methods and planting characteristics. Data regarding the number of cultivated specimens, altitude, use of irrigation, soil acidity correction, incidence of pests, flowering period, climate characteristics, age, and vitality of $P$. viridis plantings were obtained by means of a questionnaire answered by the person responsible at each site. These data were used to select 25 sites that were the most representative in terms of different environmental conditions and cultivation, as well as having the largest $P$. viridis plantations in the UDV.

\section{Sample preparation and chemical analyses}

Upon receipt, each sample of leaves was cleaned with deionized water, dried at $55{ }^{\circ} \mathrm{C}$ until constant weight was achieved, and fragmented in a knife mill. The homogenized plant material was stored in polyethylene flasks protected from light and humidity and kept under controlled temperature $\left(20 \pm 2{ }^{\circ} \mathrm{C}\right)$ until analysis. Extracts of leaves were obtained through a modification of the method suggested by Callaway. ${ }^{14}$ Powdered leaves of $P$. viridis $(0.25 \mathrm{~g})$ were treated with a mixture of methanol, acetonitrile, and ammonium acetate solution $\mathrm{pH} 8.0$ $(67: 11: 22 \mathrm{v} / \mathrm{v} / \mathrm{v})$ in an ultrasound bath for $30 \mathrm{~min}$. After filtration, the residual material was submitted to a second extraction process. Analyses using gas chromatography coupled to mass spectrometry (GC-MS) were carried out in parallel to ensure that the extraction was performed quantitatively. The analysis of extracts through GC-MS was conducted using a quadrupole chromatograph (Agilent model $6890 \mathrm{~N}$ ) equipped with a mass selective detector (Agilent Technologies 5973) operating at $70 \mathrm{eV}$, and using a DB-1MS column as the stationary phase and helium gas $\left(0.8 \mathrm{~mL} \mathrm{~min}^{-1}\right)$ as the mobile phase. Analytical conditions used were: injector at $280{ }^{\circ} \mathrm{C}$; split (140:1), temperature $150{ }^{\circ} \mathrm{C}(2 \mathrm{~min}), 40{ }^{\circ} \mathrm{C} \min ^{-1}, 315^{\circ} \mathrm{C}$ (4.87 min); total run,
$9.0 \mathrm{~min}$; mass detector, scan $(40-550 \mathrm{~m} / \mathrm{z})$; solvent delay, $1.80 \mathrm{~min}$; and injected volume, $0.2 \mu \mathrm{L}$. The quantitative analyses were conducted using external calibration and tryptamine as an internal standard. All analyzes were done in triplicate and the mean value was used. The DMT used as a standard was obtained through synthesis using the methodology proposed by Pires et al. ${ }^{15}$ adapted from Giumanini and Musiani. ${ }^{16}$

\section{Macro and micronutrients evaluation}

The content of macro (N, P, K, Ca, and $\mathrm{Mg}$ ) and micro ( $\mathrm{S}, \mathrm{B}, \mathrm{Mn}, \mathrm{Cu}$, and $\mathrm{Zn}$ ) nutrients in the leaves of $P$. viridis were measured using specific methods. The quantitative analysis of organic nitrogen was performed using a Tecnal TE-036/1 apparatus, according to the semi-microKjeldahl method suggested by Malavolta. ${ }^{17}$ Potassium was determined using a Digimed flame photometer, model DM-62. The elements $\mathrm{Cu}, \mathrm{Mn}$, and $\mathrm{Zn}$ were evaluated on a Variant 12/1475 atomic absorption spectrometer, and $\mathrm{Ca}$ and $\mathrm{Mg}$ on a PerkinElmer AAnalyst 300 atomic absorption spectrometer. The spectrophotometer FEMTO model 600 Plus was used for the colorimetric analysis of B, S, and P. Azomethine $\mathrm{H}$ was used for the determination of boron, barium sulfate for sulfur, and molybdate/metavanadate for analysis of total phosphorous. A shaker table Novatecnica model 145 was used in the analysis of sulfur content. The analyses of micro- and macronutrients were completed in the laboratories of the Fundação Pró-Café, Varginha City, Minas Gerais State, Brazil.

\section{Environmental data}

The rainfall index $\left(\mathrm{mm}\right.$ year $\left.{ }^{-1}\right)$ was obtained from the electronic site of the Instituto Nacional de Meteorologia (INMET), ${ }^{18}$ Brazil. Data relating to $P$. viridis farming methods (use of irrigation and correction of soil acidity) and characteristics of planting (presence of flowering and pest infestation, evaluation of the vitality of plants) were provided by the sampler of each nucleus (an experienced member of the UDV), which also was responsible for mailing the leaf samples. Biomes in which the sites of the UDV were located were established in accordance with online data available from the Instituto Brasileiro de Geografia e Estatística (IBGE). ${ }^{19}$

\section{Vitality of the $P$. viridis crop}

The vitality of the $P$. viridis plantations was assessed by the sample collectors, which were experienced members of the UDV and generally responsible for the crops. To 
establish the plant status, the values 1 to 4 were adopted. The value 1 was given to plantations with low vitality and heavily affected by pests, malnutrition or drought and under risk to not resisting to environmental conditions; value 2 to plantations that were in conditions of low growth, affected by adverse environmental conditions, however, without risk of death; 3 to healthy plants with green leaves and size compatible with the average of the species, and 4 was attributed to exuberant plantations, with very healthy specimens, without any prominent effects of pest or drought.

\section{Statistical analysis}

The mean value of micro- and macronutrients and of DMT in leaves of $P$. viridis, together with the data related to environmental and growing conditions were submitted to the following statistical methodology. A linear model containing the factors: site, time of collection (season), and an interaction term was fitted to the trait DMT. For some sites, it was not possible to obtain samples for all four seasons, resulting in an unbalanced dataset. Model fitting was conducted using the procedure "glm" of the software SAS, ${ }^{20}$ and $F$-tests resulted from type III sums of squares, which are appropriate when data are unbalanced. To better understand the interaction between sites and seasons, a reparametrized model was also fitted, with sites nested within seasons. To discriminate the site groups in each season, we applied the Scott-Knott grouping method. ${ }^{21}$

In each available combination of site and harvest time, there was information regarding the following factors: (i) blooming at sampling; (ii) use of irrigation; (iii) pest occurrence; $(i v)$ soil acidity correction; and $(v)$ vigor of planting. The first four factors were binary (yes/no), and the latter corresponded to a grade ranging from 1 to 4 . The covariates latitude, longitude, and altitude of each site were also considered, as well as rainfall during the month of data collection in each site town. The influences of each of the factors and covariates on DMT content were determined by introducing it and its interactions with sites (when applicable) and seasons in the original model. $F$-Tests using type I (also called sequential) sums of squares (SS) were calculated, considering the following order in the analysis of variance (ANOVA): factor or covariate (SS1), season $(\mathrm{SS} 2)$, site $(\mathrm{SS} 3)$, interaction factor (or covariate) $\times$ site, when applicable (SS4), interaction factor (or covariate) $\times$ season (SS5), and interaction site $\times$ season (SS6). To determine how much of the total variation caused by sites, seasons, and their interaction could be attributed to each of the factors or covariates, the following coefficient of determination was defined: $\mathrm{R}^{2}=(\mathrm{SS} 1+\mathrm{SS} 4+\mathrm{SS} 5) /(\mathrm{SS} 1+\mathrm{SS} 2+\mathrm{SS} 3+\mathrm{SS} 4+\mathrm{SS} 5$
$+\mathrm{SS} 6)$

To determine which variables (nutrients) were associated with DMT and the magnitude of these associations, multiple regression models were constructed by the stepwise method. Initially all independent variables were included in the model, leaving only significant variables in the subsequent models. Some interactions were also included at this stage.

Analyses of residuals of each model were performed to assess validity of assumptions of normality, homoscedasticity, and independence between observations. The statistics Cook's distance and variance inflation factor (VIF) were used to identify outliers and to check for possible multicollinearity between independent variables. ${ }^{22}$ In this study, the significant level was $\alpha=0.05$ for all statistical tests. The statistical software $\mathrm{R}$ version $3.3 .1^{23}$ was used in the analysis of the multiple linear regression model.

For statistical analyses, the site Arco-íris was not used in the dataset, because it was the only one that cultivated $P$. viridis in a greenhouse with an artificial microclimate in which the temperature and rainfall were controlled.

\section{Results and Discussion}

\section{Biomes}

Brazil is divided into six great biomes (Figure 1): Amazon, Cerrado, Caatinga, Atlantic forest, Pantanal, and Pampa. ${ }^{19,24}$ The Amazon biome occupies $49.29 \%$ of the national territory and is defined according to the climate unit, forest physiognomy, and geographic location.

The Atlantic Forest biome, which occupies the entire Brazilian continental Atlantic coast and extends inland to the southeast and south of the country is characterized by a typical forest vegetation and varies in geographic relief. The Cerrado is ranked as the second largest in Brazil stretching from the Maranhão coast to the midwestern area. The Caatinga is typical of the semi-arid climate of the northeastern backlands. The Pantanal is considered the smallest land area in Brazil (1.76\%), but is one of the largest continuous wetlands on the planet. Finally, the Pampa biome is restricted to the Rio Grande do Sul State and characterized by a set of field vegetation in plain relief. ${ }^{19,24}$

The DMT concentration in leaves from samples collected in April (autumn), July (winter), and October (spring) 2013, and in January 2014 (summer) were analyzed by GC-MS (Table 1). The site Mestre Adamir had two different plantations and consequently two samplings were conducted at this site. 


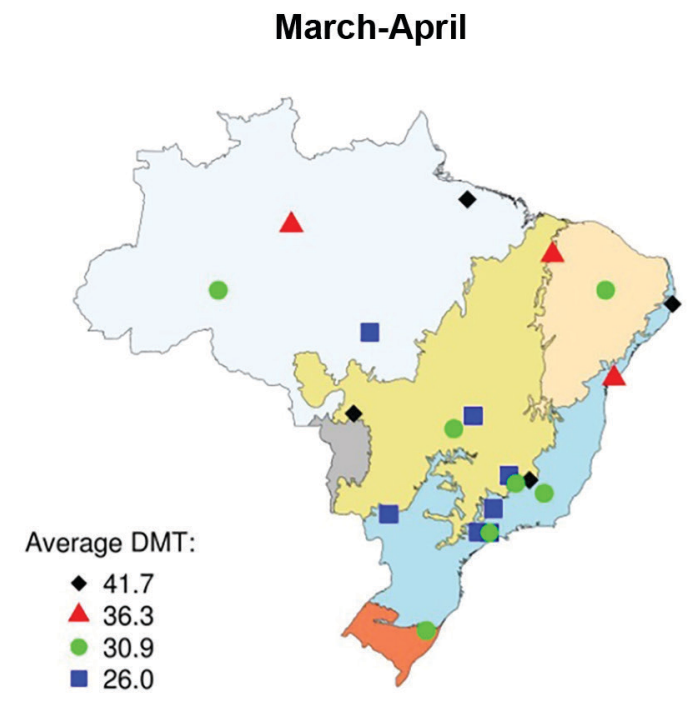

September-October

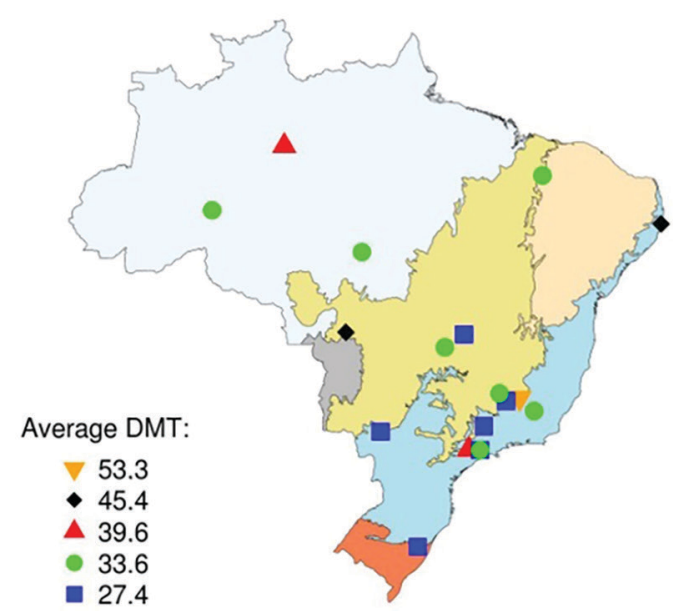

June-July

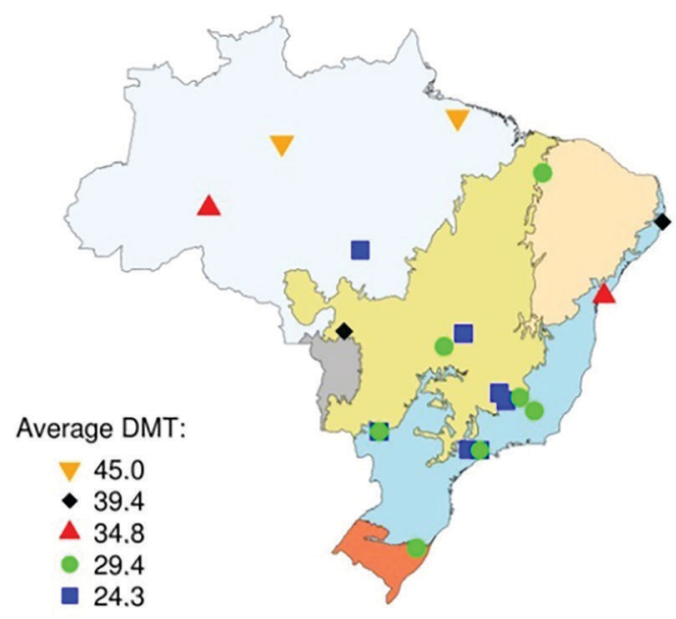

December-January

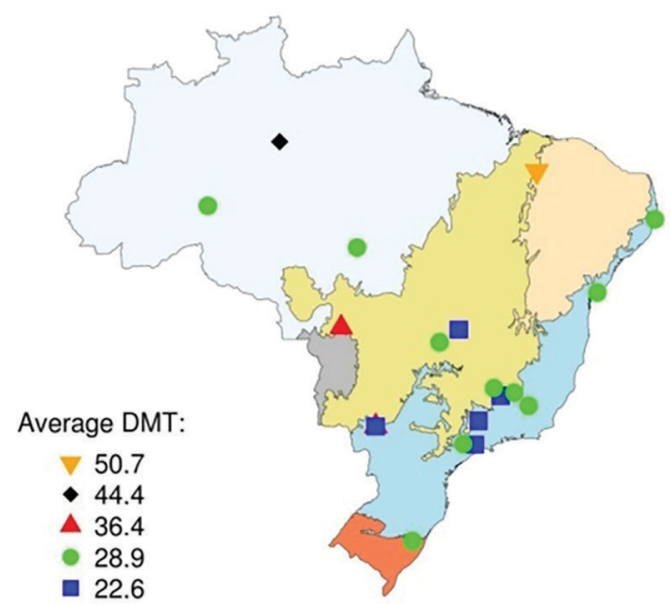

Figure 1. Geographic position of the UDV nuclei located at biome Amazon ( $\square$ ), Pantanal ( $\square$ ), Atlantic forest ( $\square$ ), Pampa ( $\square$ ) and Cerrado ( $\square$ ). The symbols inserted outside maps correspond to the DMT average values $\left(\mathrm{mg} \mathrm{g}^{-1}\right)$ in leaves of Psychotria viridis found in different UDV sites. Symbols of same color and shape represent values of the mean concentration of DMT that were statistically similar. For those with different colors and shapes the mean results were statistically different.

The DMT concentrations were analyzed in relation to the type of biome in which the $P$. viridis plantations were located (Figure 1, Table 1). However, even when the official classification indicated that the site belonged to one of these biomes, they were often located in transition zones sharing environmental characteristics of the two interfaced biomes (Figure 1, Table 1). For this reason, sites located in transition zones were considered as being in the following categories of interfaced biomes: Cerrado $\leftrightarrow$ Atlantic Forest, Cerrado $\leftrightarrow$ Caatinga, and Atlantic Forest $\leftrightarrow$ Pampa (Table 1).

The average DMT concentration $\left(\mathrm{mg} \mathrm{g}^{-1}\right)$ in dried leaves of $P$. viridis by biome was in the order of Atlantic Forest (29.6), Cerrado (29.6), Pampa $\leftrightarrow$ Atlantic Forest (30.5),
Atlantic Forest $\leftrightarrow$ Cerrado (31.1), Amazon (35.8), Caatinga (36.1), and Cerrado $\leftrightarrow$ Caatinga (37.3). The average concentrations of DMT presented two distinct ranges of values. For the biomes Amazon, Caatinga, and Caatinga $\leftrightarrow$ Cerrado, the average concentration of DMT was similar (median ca. $36.3 \mathrm{mg} \mathrm{g}^{-1}$ ), and the concentration for the Atlantic Forest, Cerrado, Atlantic Forest $\leftrightarrow$ Cerrado, and Atlantic Forest $\leftrightarrow$ Pampa biomes was lower (median $\left.=29.9 \mathrm{mg} \mathrm{g}^{-1}\right)$. Biomes with the lowest DMT concentrations were the Cerrado and Mata Atlântica, both with an average concentration of $29.6 \mathrm{mg} \mathrm{g}^{-1}$. Further, in comparison to the values found for the Amazon biome, with a mean DMT value of $35.8 \mathrm{mg} \mathrm{g}^{-1}$, the concentrations were $17.3 \%$ less. The smallest DMT content was found 
Table 1. Mean value of the DMT in leaves of Psychotria viridis collected at nucleus of UDV located in different municipalities of Brazilian States that comprise specific Brazilian biomes

\begin{tabular}{|c|c|c|c|c|}
\hline \multirow[b]{2}{*}{ UDV nucleus (Municipality, State) } & \multicolumn{4}{|c|}{ DMT $($ mean $\pm \mathrm{sd}) /\left(\mathrm{mg} \mathrm{g}^{-1}\right)$} \\
\hline & $\begin{array}{c}\text { Collection } 1 \\
\text { April } 2013\end{array}$ & $\begin{array}{l}\text { Collection } 2 \\
\text { July } 2013\end{array}$ & $\begin{array}{l}\text { Collection } 3 \\
\text { October } 2013\end{array}$ & $\begin{array}{c}\text { Collection } 4 \\
\text { January } 2014\end{array}$ \\
\hline \multicolumn{5}{|c|}{ Atlantic Forest } \\
\hline Arco-íris (Joaçaba, SC) & $42.60 \pm 2.4$ & $46.77 \pm 4.2$ & $51.35 \pm 3.1$ & $37.91 \pm 0.9$ \\
\hline Cajueiro (Recife, PE) & $40.03 \pm 1.8$ & $40.14 \pm 1.7$ & $44.39 \pm 3.4$ & $29.73 \pm 2.2$ \\
\hline Divino Manto (São Paulo, SP) & $25.94 \pm 0.7$ & $29.32 \pm 2.2$ & $27.83 \pm 2.4$ & $21.78 \pm 1.7$ \\
\hline Estrela da Manhã (Camaçari, BA) & $37.42 \pm 0.8$ & $34.54 \pm 3.3$ & - & $30.28 \pm 0.6$ \\
\hline Rainha das Águas (Caldas, MG) & $25.39 \pm 1.5$ & $23.66 \pm 3.8$ & $25.75 \pm 1.5$ & $22.84 \pm 0.2$ \\
\hline Recanto das Flores (Ubá, MG) & $31.18 \pm 0.1$ & $29.55 \pm 2.3$ & $32.66 \pm 1.4$ & $27.90 \pm 2.5$ \\
\hline Rei Divino (São Paulo, SP) & $28.68 \pm 1.3$ & $25.72 \pm 1.6$ & $28.88 \pm 1.3$ & $20.17 \pm 1.7$ \\
\hline Samaúna (São Paulo, SP) & $26.34 \pm 2.7$ & $27.38 \pm 0.7$ & $36.49 \pm 2.4$ & $20.38 \pm 1.2$ \\
\hline \multicolumn{5}{|c|}{ Cerrado } \\
\hline Lupunamanta (Campinas, SP) & $24.03 \pm 0.3$ & $26.39 \pm 1.9$ & $40.51 \pm 1.4$ & $29.06 \pm 1.9$ \\
\hline Arvoredo (Cuiabá, MT) & $41.48 \pm 1.5$ & $38.61 \pm 2.6$ & $46.31 \pm 1.9$ & $35.23 \pm 1.6$ \\
\hline Luz de Maria (Campo Grande, MS) & $28.29 \pm 1.4$ & $23.28 \pm 1.1$ & $28.34 \pm 1.3$ & $37.64 \pm 1.7$ \\
\hline São Joaquim (Campo Grande, MS) & $27.76 \pm 3.5$ & $28.66 \pm 1.6$ & - & $24.70 \pm 0.6$ \\
\hline Rei Inca (Goiânia, GO) & $22.68 \pm 1.6$ & $30.49 \pm 2.8$ & $30.81 \pm 1.6$ & $23.24 \pm 0.9$ \\
\hline Canário Verde (Brasília, DF) & $24.79 \pm 1.9$ & $21.82 \pm 1.9$ & $26.29 \pm 1.7$ & $22.69 \pm 0.6$ \\
\hline \multicolumn{5}{|c|}{ Pampa $\leftrightarrow$ Atlantic forest } \\
\hline Jardim das Flores (Porto Alegre, RS) & $32.38 \pm 3.2$ & $30.47 \pm 1.8$ & $27.71 \pm 0.8$ & $31.61 \pm 2.5$ \\
\hline \multicolumn{5}{|c|}{ Atlantic forest $\leftrightarrow$ Cerrado } \\
\hline Flor Encantadora (Sabará, MG) & $45.15 \pm 1.9$ & $29.08 \pm 1.6$ & $53.30 \pm 4.3$ & $26.17 \pm 2.4$ \\
\hline Flor de Mariri (Divinópolis, MG) & $30.93 \pm 0.2$ & $22.74 \pm 1.0$ & $27.27 \pm 2.1$ & $25.35 \pm 0.9$ \\
\hline Lagoa da Prata (Lagoa da Prata, MG) & $25.39 \pm 1.8$ & $25.45 \pm 2.2$ & $32.59 \pm 2.6$ & $29.43 \pm 1.8$ \\
\hline \multicolumn{5}{|c|}{ Caatinga } \\
\hline Flor Divina (Fortaleza, CE) & $33.77 \pm 5.6$ & $36.52 \pm 5.7$ & $41.79 \pm 6.0$ & $34.33 \pm 4.6$ \\
\hline Santa Fé do Cariri (Crato, CE) & $31.37 \pm 1.4$ & $36.08 \pm 3.2$ & $41.12 \pm 4.3$ & $34.16 \pm 2.0$ \\
\hline \multicolumn{5}{|c|}{ Cerrado $\leftrightarrow$ Caatinga } \\
\hline Mestre Adamir I (Terezina, PI) & $30.48 \pm 1.5$ & $31.04 \pm 0.6$ & $35.17 \pm 1.9$ & $41.66 \pm 3.8$ \\
\hline Mestre Adamir II (Terezina, PI) & $39.78 \pm 2.3$ & $29.93 \pm 0.3$ & $30.91 \pm 2.1$ & $59.64 \pm 5.3$ \\
\hline \multicolumn{5}{|c|}{ Amazon } \\
\hline Florestal (Alta Floresta, MT) & $26.43 \pm 1.0$ & $24.46 \pm 1.3$ & $34.90 \pm 1.3$ & $26.14 \pm 2.0$ \\
\hline Mestre Rubens (Jarú, RR) & $31.13 \pm 0.8$ & $35.07 \pm 2.0$ & $34.37 \pm 1.4$ & $32.04 \pm 1.6$ \\
\hline Rei Canaã (Belém, PA) & $39.98 \pm 2.9$ & $43.14 \pm 1.0$ & $38.09 \pm 2.6$ & $41.30 \pm 3.9$ \\
\hline Águas Claras (Manaus, AM) & $36.38 \pm 5.0$ & $46.79 \pm 1.0$ & $38.74 \pm 1.8$ & $44.44 \pm 1.9$ \\
\hline
\end{tabular}

AM: Amazonas; PE: Pernambuco; CE: Ceará; SP: São Paulo; MG: Minas Gerais; GO: Goiás; DF: Distrito Federal; SC: Santa Catarina; RS: Rio Grande do Sul; MT: Mato Grosso; MS: Mato Grosso do Sul; PA: Pará; RR: Roraima; PI: Piauí; ↔: biome interface; sd: standard deviation.

in samples of $P$. viridis collected from the site Rei Divino (20.17 $\mathrm{mg} \mathrm{g}^{-1}$ ) of the Atlantic forest biome and the highest value from the site Mestre Adamir (59.64 $\mathrm{mg} \mathrm{g}^{-1}$ ) in the Cerrado $\leftrightarrow$ Caatinga biomes interface (Table 1).

In comparison to the other biomes, the Atlantic Forest biome had the lowest average DMT value $\left(29.6 \mathrm{mg} \mathrm{g}^{-1}\right)$. However, samples of $P$. viridis from the Arco-íris site had the greatest average value of DMT (44.66 $\mathrm{mg} \mathrm{g}^{-1}$ ) (Table 1). This site was the only one where $P$. viridis was cultured under environmentally controlled conditions in greenhouses. The Arco-íris site was located in Santa Catarina State, southern region of Brazil. Compared to the Amazon biome, the Atlantic Forest biome is characterized by lower temperatures. Within 30 days prior to collection, 
the following minimal median temperatures were observed: April, $14.4{ }^{\circ} \mathrm{C}$; July, $9.7^{\circ} \mathrm{C}$; October, $9.8^{\circ} \mathrm{C}$; and January, $15.3{ }^{\circ} \mathrm{C} .{ }^{18}$ The use of a greenhouse by Arco-íris site provided adequate conditions for $P$. viridis to produce higher concentrations of DMT in the Atlantic Forest biome.

\section{Seasonality}

The nature and content of active constituents in plants varies during the year. Therefore, the period of year in which the plant material is harvested is an important parameter to consider. Throughout the studied period, the concentration of DMT in P. viridis leaves ranged from 12.7 to $103.7 \%$ at the same site, with $38.5 \%$ average variation (Table 1). Regarding seasonality, the Amazon biome was relatively stable in DMT concentrations for the same site, with the median value oscillating around $24.3 \%$ (Table 1 ). In the Amazon region, seasonality is not usually observed in terms of significant thermal variation, although the climate is characterized by a dry and wet distinct period. It is likely that this thermal stability in the Amazon region is the main factor that minimizes variations in the concentration of DMT.

\section{Altitude, latitude, and longitude}

It is noteworthy that the covariates altitude, latitude, and longitude likely presented correlations only at the time of collection. This statement is justified because in each UDV site, the covariates latitude, longitude, and altitude remained constant. However, to confirm possible significant interactions, regression coefficients were estimated. Among the factors that contributed to DMT variation, altitude presented the highest coefficient of determination $\left(\mathrm{R}^{2}\right)$ for this compound (Table S1, SI section).

A positive association was found between latitude and DMT content in the leaves of $P$. viridis. It was observed that DMT declined with movement away from the equator, towards the south. All estimative were positive and statistically significant. For DMT variation, approximately $28.4 \%$ was explained by latitude. The results were less clear regarding longitude: a positive association was observed in winter and negative association in summer. For autumn and spring, there was no statistical significance.

\section{Rainfall index}

Water availability plays a crucial role in a variety of plant physiological processes, such as photosynthesis, increases in leaf mass, mobilization of reserves, growth, and others. In addition, rainwater brings an important contribution of mineral nutrients that are added directly to the nutrient reservoir available to the plant and represents one of the main inputs of $\mathrm{K}, \mathrm{Ca}, \mathrm{N}$, and $\mathrm{P}$ to the soil. ${ }^{25}$ The rainfall index can exert a positive or negative influence on the production of the active components of plants. The effect of drought on the production of active components depends on the degree of water stress. If the period of drought is short, the production of some constituents is increased, but if it is prolonged, the concentration decreases.

Brazil is a country with a large territory containing different types of ecosystems and a variety of climates, and consequently the distribution of rainfall occurs unevenly. Although large volumes of rainfall occur in the tropical forests of the Amazon region, in the Caatinga (northeast region of Brazil), long periods of drought are observed, which can last for years. The fact that there were no agro-climatological stations at the vicinity of all sites is a limitation of this study. Consequently, rainfall indices were obtained from climatologic stations closest to the studied sites. This fact may not accurately reflect the real indices at planting sites. Given the immense Brazilian territory and the great distances between the cities in the Amazon region, this limitation is unavoidable. The average amount of rainfall during the 30 days prior to sampling was considered in the statistical analysis (Table S2, SI section). The effect of the rainfall index on DMT concentration was statistically significant in winter (collection 2, July) and summer (collection 4, January) (Table 1, Table S2). In winter, a period characterized by low incidence of rainfall (collection 2, July), it was observed that DMT production increased with increases in the rainfall index. In summer, a season characterized by high rainfall, the effect was negative; that is, the increase in the rainfall index induced P. viridis to decrease its DMT production (collection 4, January) (Table 1, Table S2). This reduction in the DMT content can be explained by the dilution of DMT in the tissues of the plant (growth of new plant tissues).

It should be emphasized that for the extensive cultivation of $P$. viridis the use of soil irrigation is common, which alleviates the effects of water stress during drier periods, providing the plants with a regular supply of water. Nonetheless, it was possible to estimate a value of approximately $14.1 \%$ contribution of the rainfall index to the variation in DMT concentration.

\section{Flowering and incidence of pests}

In general, during the flowering period, plants increase the production of their active components. Thus, a statistical difference was detected between flowering and DMT variation in winter, spring, and summer. This association explained $8.1 \%$ of the variation in DMT levels. 
Pest attacks can lead the plant to produce a biochemical response, which induces the synthesis of compounds used for defense. The increase in alkaloid production is one example of this type of response. Several pest attacks have been reported in the $P$. viridis plantations, at low, medium and large incidence degrees. According to the representative from the UDV sites, the most common type of pests that affected the $P$. viridis crop were: caterpillars, ants, fungi, grasshoppers, aphids and plant diseases caused by pathogenic fungi (rusts). Statistical significance was found between the presence of pests in the plantation and DMT variation in autumn and spring explaining $3.2 \%$ of DMT level variation. This contribution was relatively small compared to other factors that influenced DMT levels.

\section{Correction of soil acidity and irrigation}

Limestone, mineral phosphate, rock dust MB4 $\left(\right.$ MIBASA $\left.^{\circledR}\right)$, bone meal and ash were used to make soil acidity correction. The correction of soil acidity was statistically significant for DMT levels in leaves of $P$. viridis during all seasons. Correction of acidity is particularly important in acidic environments, such as the Brazilian Cerrado soil. Acidic soils may impair soil nutrient uptake and acidity correction increases the availability of nutrients such as $\mathrm{N}, \mathrm{P}, \mathrm{K}, \mathrm{Ca}, \mathrm{Mg}$, and $\mathrm{S}$. Acidity correction and its interactions with sites and seasons accounted for $11.25 \%$ of the DMT variation (sums of squares) associated with sites, seasons and the interaction among these factors, according to the coefficient of determination previously defined.

Irrigation of $P$. viridis crop is widely used in the UDV sites. The two main types of irrigation systems used in UDV plantations are sprinkling and drip irrigation. This occurs mainly in the Cerrado biome. The effect of irrigation on DMT levels was not statistically significant.

\section{Vitality of $P$. viridis crop}

Regarding the feasibility of planting $P$. viridis and DMT production, statistical significance was found in the evaluations conducted for the period of analysis. The associations were positive in all seasons, that is, better classification of planting in terms of the vitality of $P$. viridis resulted in higher DMT levels. This result was expected, because plants with good vitality produce greater content of substances. The fact that statistical significance occurred in all seasons is an indication that the subjective evaluation by collectors of the samples represented the quality of the plantations relatively well and that there is a relationship between the "quality" of the crop and the DMT levels.
The coefficients of determination $\mathrm{R}^{2}(\%)$ of DMT related to the covariates altitude, latitude and rainfall, least square means of levels of vitality, soil correction of acidity, flowering, pest incidence and irrigation for each collection, as determined according to the $F$-test (two means) or Tukey's test (three or four means) at $p \leq 0.05$ are presented in Table S1 (SI section).

\section{Micronutrients}

Foliar analysis is an adequate method to evaluate the nutritional condition of the plant. The mineral composition in plant tissues is influenced by several factors related to the plant itself and to the environment in which it lives. The most important factors include species variety, vegetative stage, plant age, root size and efficiency, climatic variations, availability of water and nutrients in the soil, interactions among nutrients, their distribution in the environment, and type and management of ground. ${ }^{26}$ The critical physiological level of a given nutrient is defined as the concentration value that separates the ratio from deficiency and sufficiency. Above the critical level, the probability of raising the production of metabolites by the addition of nutrient is low. On the other hand, below the critical level, the rate of growth, vitality and production of the plant are compromised. ${ }^{26}$ No studies on the critical nutrient values for $P$. viridis were found in the literature. In addition, there have been no studies correlating the concentration of DMT with the levels of micronutrients for $P$. viridis. For crops of high economic and social value, such as coffee (Coffea sp.) in the family Rubiaceae, the same family as $P$. viridis, there have been numerous studies correlating crop productivity with critical levels of micronutrients. Considering they are in the same family, a comparison was made between the critical values of the nutrient contents of coffee suggested by some authors, ${ }^{17,27,28}$ with the nutrient contents found in P. viridis. The goal of these comparisons was to establish an initial reference with which to evaluate the nutritional status of $P$. viridis.

In the samples of dried $P$. viridis leaves, average levels of micronutrients in decreasing order of concentration were $\mathrm{N}>\mathrm{Ca}>\mathrm{K}>\mathrm{Mg}>\mathrm{P}>\mathrm{S}>\mathrm{B}>\mathrm{Zn}>\mathrm{Mn}>\mathrm{Cu}$ (Table 2). Table S3 (SI section) contains all data related to $P$. viridis micronutrient concentration.

Regarding metals, copper presented the lowest concentration in the foliar tissue. This result may have occurred because copper is the micronutrient that interacts most strongly with organic compounds in the soil especially with carboxylic and phenolic groups, forming stable organometallic compounds. ${ }^{29}$ The critical mean content of $\mathrm{N}$ and $\mathrm{Mn}$ found in P. viridis were lower than those of coffee, whereas the mean values of $\mathrm{P}, \mathrm{Zn}$, and $\mathrm{B}$ were 
Table 2. Levels (mean $\pm \mathrm{sd}$ ) of micronutrients found in leaves of $P$. viridis compared to the critical range values ${ }^{\mathrm{a}}$ suggested for leaves of $C$ offea arabica $\mathrm{L}$.

\begin{tabular}{lcccc}
\hline & \multicolumn{4}{c}{ Average content in dried leaves } \\
\cline { 2 - 4 } Micronutrient & \multicolumn{3}{c}{ Critical range values for Coffea arabica $^{\mathrm{a}}$} & P. viridis \\
\cline { 2 - 4 } & Mills and Jones $^{27}(1996)$ & Malavolta et al. $^{17}(1997)$ & Matielo $^{28}(1997)$ & $2.23 \pm 0.20$ \\
\hline $\mathrm{N} /\left(\mathrm{dag} \mathrm{kg}^{-1}\right)$ & $2.30-3.00$ & $2.90-3.20$ & $3.00-3.05$ & $0.21 \pm 0.07$ \\
$\mathrm{P} /\left(\mathrm{dag} \mathrm{kg}^{-1}\right)$ & $0.12-0.20$ & $0.16-0.19$ & $0.12-0.20$ & $1.85 \pm 0.34$ \\
$\mathrm{~K} /\left(\mathrm{dag} \mathrm{kg}^{-1}\right)$ & $2.00-2.50$ & $2.20-2.50$ & $1.80-2.50$ & $1.86 \pm 0.50$ \\
$\mathrm{Ca} /\left(\mathrm{dag} \mathrm{kg}^{-1}\right)$ & $1.00-2.50$ & $1.30-1.50$ & $1.00-1.50$ & $0.37 \pm 0.06$ \\
$\mathrm{Mg} /\left(\mathrm{dag} \mathrm{kg}^{-1}\right)$ & $0.25-0.40$ & $0.40-0.45$ & $0.35-0.50$ & $0.16 \pm 0.03$ \\
$\mathrm{~S} /\left(\mathrm{mg} \mathrm{g}^{-1}\right)$ & $0.10-0.20$ & $0.15-0.20$ & $0.15-0.20$ & $32.4 \pm 12.3$ \\
$\mathrm{Zn} /\left(\mathrm{mg} \mathrm{g}^{-1}\right)$ & $12.0-30.0$ & $15.0-20.0$ & $10.0-20.0$ & $32.2 \pm 9.8$ \\
$\mathrm{Mn} /\left(\mathrm{mg} \mathrm{g}^{-1}\right)$ & $50.0-200.0$ & $80.0-100.0$ & $50.0-100.0$ & $11.2 \pm 3.4$ \\
$\mathrm{Cu} /\left(\mathrm{mg} \mathrm{g}^{-1}\right)$ & $10.0-25.0$ & $11.0-14.0$ & $10.0-50.0$ & $87.0 \pm 30.5$ \\
$\mathrm{~B} /\left(\mathrm{mg} \mathrm{g}^{-1}\right)$ & $40.0-75.0$ & $50.0-60.0$ & $40.0-80.0$ & \\
\hline
\end{tabular}

${ }^{\mathrm{a}}$ Minimum and maximum physiologically adequate for $C$. Arabica growth. sd: standard deviation.

higher. At concentrations ranging from 20 to $35 \mathrm{mg} \mathrm{kg}^{-1}$, symptoms of Mn deficiency were already observed in C. arabica leaves, probably because of excessive liming. ${ }^{17}$ Thus, it is obvious that fertilization influences the level of nutrients in P. viridis. Except for the site Lagoa da Prata in Minas Gerais, Brazil, the $P$. viridis plantings were fertilized. However, the types of fertilizers used were diverse: mature compost, manure, MB4 (MIBASA ${ }^{\circledR}$ ), bagasse, bone meal, eggshell, rock powder, limestone, and organic fertilizers. Based on the adequate content suggested for $C$. arabica the mean for the nutrients $\mathrm{K}, \mathrm{Ca}, \mathrm{Mg}, \mathrm{S}$ and $\mathrm{Cu}$ were within the appropriate range for $P$. viridis (Table 2).

A positive association between the content of $\mathrm{N}$ and Mg with DMT concentration was revealed with statistical analyses. However, for $\mathrm{N}$, statistical significance for samples occurred for those collected in April (collection 1) and January (collection 4), and in April (collection 1) for Mg (Table S3, SI section). The biosynthesis of alkaloids depends on nitrogen availability, and thus this positive association was expected. Similar results were found by Vojnich et al., ${ }^{30}$ who demonstrated that fertilization of Lobelia inflata L. with magnesium and nitrogen influenced the biosynthesis of lobeline, an alkaloid that induces respiratory center stimulation. An increase of approximately $20 \%$ in lobeline was observed after the addition of magnesium and of about $9 \%$ following the addition of nitrogen.

Statistical analysis revealed a negative association for the levels of $\mathrm{P}$ (autumn and spring), S (spring and summer), $\mathrm{Mn}$ (autumn and winter), and $\mathrm{Cu}$ (winter) and DMT concentration (Table S3, SI section). No clear trend could be observed for the elements $\mathrm{Ca}, \mathrm{Zn}$, and B.

Regression analysis of micronutrient concentration in dried leaves was conducted and the following equations were established to estimate adequate nutrient supplementation that would improve the production of DMT by $P$. viridis:
Based on data of collection 1:

$9.87 \mathrm{~N}-20.82 \mathrm{P}+5.18 \mathrm{Ca}+109.80 \mathrm{Mg}-0.20 \mathrm{Zn}-$

$0.30 \mathrm{Mn}\left(\mathrm{R}^{2}=0.63\right)$

Based on data of collection 2:

$-0.22 \mathrm{Mn}+0.49 \mathrm{Zn}-1.57 \mathrm{Cu}-0.12 \mathrm{~B}\left(\mathrm{R}^{2}=0.76\right)$

Based on data of collection 3:

$-55.0 \mathrm{P}-119.70 \mathrm{~S}\left(\mathrm{R}^{2}=0.22\right)$

Based on data of collection 4:

$17.44 \mathrm{~N}-10.46 \mathrm{Ca}-132.78 \mathrm{~S}+0.13 \mathrm{~B}\left(\mathrm{R}^{2}=0.48\right)$

In these equations, the importance is not the absolute value, rather than that, it is essential to determine if the signal is positive or negative. A positive signal indicates that the addition of a nutrient will enhance DMT concentration. For example, based on the regression analysis for the data from collection 1 , the micronutrients that contributed to DMT enhancement were N, Ca, and Mg. Conversely, an increase in $\mathrm{P}, \mathrm{Mn}$, or $\mathrm{Zn}$ supplementation would reduce DMT concentration in P. viridis.

Using the equations, we could verify the significance of the correlation between each micronutrient and DMT concentration in leaves of $P$. viridis collected in UDV plantations distributed in different Brazilian biomes. These equations could be used to estimate an adequate foliar supplementation that would result in a concentration of DMT similar to that produced by Amazonian P. viridis.

\section{Content of DMT in the same site}

Even among cultivated plants that grow side by side, in the similar environmental conditions, certain differences occur in the content of active components. This is caused 
by genetic variation, age differences among plants, soil characteristics, access to sunlight, and other environmental factors. To evaluate the variation of DMT within the same site, 10 samples were collected from 10 specimens at each site, totaling 100 samples (6 leaves per specimen). Based on the relative standard deviation, the intra-site DMT content ranged from 5.73 to $16.55 \%$.

The number of factors that interfere in plant production of secondary metabolites is large and varied, which makes it complex to evaluate them simultaneously. Each of the evaluated factors considered in the present work open questions to be studied separately in detail and under controlled conditions. For example, studies on the effects of micronutrients on DMT concentration could be performed under controlled conditions. Some important factors remain unstudied, such as the influence of genetic parameters, incidence of sunlight, and specific soil characteristics.

\section{Conclusions}

The environmental factors responsible for the greatest contribution to DMT variation in P. viridis were seasonality, altitude, latitude, and biome type. Throughout the study period, the concentration of DMT in $P$. viridis leaves varied by a mean of $38.5 \%$. In relation to altitude, latitude, and biome criteria, the variation of DMT reached 31.3, 28.4 and $17.3 \%$, respectively. Other parameters exhibited important contributions to the level of DMT, such as precipitation index, vitality, and soil correction, albeit to a lesser extent. A positive association between $\mathrm{N}$ and Mg content and DMT levels was detected through the statistical analysis of $P$. viridis foliar nutrient contents. In comparison to the adequate values adopted for Coffea sp., the $\mathrm{N}$ content in the leaves of $P$. viridis were below critical levels. Through this study, it was possible to elucidate some environmental factors and cultural practices that influenced the concentration of DMT in P. viridis.

\section{Supplementary Information}

Supplementary information (tabulated data used in this work) is available free of charge at http://jbcs.sbq.org.br as PDF file.

\section{Acknowledgments}

The authors thank to Fundação de Amparo à Pesquisa de Minas Gerais (FAPEMIG, project No. APQ-02045-13), Conselho Nacional de Desenvolvimento Científico e Tecnológico (CNPq, under grant 300825/2016-1), and are grateful to the 25 sites of União do Vegetal participating in this study for supplying the samples, and to Fundação Pró-Café, Minas Gerais, Brazil, for micronutrient analyses.

\section{References}

1. Santos, R. G.; SMAD, Rev. Eletrônica Saúde Mental Alcool Drog. 2007, 3, article ID 6. DOI 10.11606/issn.1806-6976. v3i1p01-11.

2. McKenna, D. J. In Ayahuasca - Human Consciousness and The Spirits of Nature, vol. 1; Metzner, R., ed.; Thunder's Mouth Press: New York, USA, 1999, p. 187; Callaway, J. C.; Brito, G. S.; Neves, E. S.; J. Psychoact. Drugs 2005, 37, 45.

3. Conselho Nacional de Políticas sobre Drogas (CONAD); Resolução No. 1, de 25 de Janeiro de 2010; Diário Oficial da União (D.O.U.), seção 1, No. 17, 26 de Janeiro de 2010. Available at https://www.jusbrasil.com.br/diarios/1574500/ pg-58-secao-1-diario-oficial-da-uniao-dou-de-26-01-2010, accessed on July 24, 2017.

4. Moffat, A. C.; Osselton, M. D.; Widdop, B.; Watts, J.; Clarke's Analysis of Drugs and Poisons, vol. 2, $4^{\text {th }}$ ed.; Pharmaceutical Press: London, UK, 2011.

5. Gable, R. S.; Addiction 2007, 102, 24; Pic-Taylor, A.; da Motta, L. G.; de Morais, J. A.; Junior, W. M.; Santos, A. F.; Campos, L. A.; Mortari, M. R.; von Zuben, M. V.; Caldas, E. D. Behav. Processes 2015, 118, 102; Soares, D. B. S.; Duarte, L. P.; Cavalcanti, A. D.; Silva, F. C.; Braga, A. D.; Lopes, M. T. P.; Takahashi, J. A.; Vieira-Filho, S. A.; An. Acad. Bras. Cienc. 2017, 89, 927.

6. Akula, R.; Ravishankar, G. A.; Plant Signaling Behav. 2011, $6,1720$.

7. Zhang, W. J.; Bjorn, L. O.; Fitoterapia 2009, 80, 207.

8. Ramakrishna, A.; Ravishankar, G. A.; Plant Signaling Behav. 2011, 6, 1720.

9. Tetényi, P.; Acta Hortic. 1983, 132, 15.

10. Castro, G. H.; Ferreira, F. A.; Rev. Bras. Plant. Med. 2001, 3, 19.

11. Al-Humaid, A. I.; J. Agric. Rural Dev. Trop. 2003, 4, 151.

12. Cakmak, I.; Yazici, A. M.; Better Crops 2010, 94, 23.

13. Gerson, E. A.; Kelsey, R. G.; J. Chem. Ecol. 1998, 24, 815.

14. Callaway, J. C. In Ayahuasca - Human Consciousness and The Spirits of Nature, vol. 1; Metzner R., ed.; Thunder's Mouth Press: New York, USA, 1999, p. 250.

15. Pires, A. P. S.; Pires, A. P.; de Oliveira, C. D.; Moura, S.; Dörr, F. A.; Silva, W. A.; Yonamine, M.; Phytochem. Anal. 2009, 20, 149.

16. Giumanini, A. G.; Musiani, M. M.; J. Prakt. Chem. 1980, 322, 423.

17. Malavolta, E.; Vitti, G. C.; Oliveira, S. A.; Avaliação do Estado Nutricional das Plantas: Princípios e Aplicações, $2^{\mathrm{a}}$ ed.; Potafos: Piracicaba, 1997. 
18. Instituto Nacional de Meteorologia (INMET); available at http://www.funceme.br/produtos/script/rede_monitoramento/ Pcd/inmet, accessed in December 2017.

19. Instituto Brasileiro de Geografia e Estatística (IBGE); Mapa de Biomas e de Vegetação; available at http://www.ibge.gov. br/home/presidencia/noticias/21052004biomashtml.shtm, accessed in November 2017.

20. Statistical Analysis System Software, v. 9.3, Cary, North Carolina, USA. Available at https://www.sas.com/en_us/ software/stat.html, accessed in December 2017.

21. Scott, A. J.; Knott, M. A.; Biometrics 1974, 30, 507.

22. Montgomery, D. C.; Peck, E. A.; Vining, G. G.; Introduction to Linear Regression Analysis, $5^{\text {th }}$ ed.; Wiley: Hoboken, NJ, USA, 2012.

23. R Core Team; R: A Language and Environment for Statistical Computing, v. 3.3.1; R Foundation for Statistical Computing, Vienna, Austria, 2016. Available at https://www.R-project.org/, accessed in December 2017.

24. Valli, M.; Pivatto, M.; Danuello, A.; Castro-Gamboa, I.; Silva, D. H. S.; Cavalheiro, A. J.; Araújo, A. R.; Furlan, M.; Lopes, M. N.; Bolzani, V. S.; Quim. Nova 2012, 35, 2278.
25. Backes, A.; Pesquisas, Botânica 2007, 58, 331.

26. Martinez, H. E.; Menezes, J. F. S.; Souza, R. B.; Venegas, V. H. A.; Guimarães, P. T. G.; Pesqui. Agropecu. Bras. 2003, 38, 703.

27. Mills, H. A.; Jones, J. B.; Plant Analysis Handbook II. A Practical Sampling, Preparation, Analysis, and Interpretation Guide; Micro-Macro Publishing, Inc.: Athens, GA, USA, 1996.

28. Matiello, J. B.; Gosto do Meu Cafezal; Ed. Globo Rural: Rio de Janeiro, Brazil, 1997.

29. de Abreu, C. A.; Lopes, A. S.; Santos, G.; In Fertilidade do Solo; Novais, R. F.; Alvarez, V. V. H.; Barros, N. F.; Fontes, R. L. F.; Cantarutti, R. B.; Neves, J. C. L., eds.; Sociedade Brasileira de Ciência do Solo, UFV: Viçosa, Brazil, 2007, p. 645-736.

30. Vojnich, V.; Máthé, Á.; Szõke, É.; Bányai, P.; Kajdi, F.; Gaál, R.; J. Cent. Eur. Agric. 2013, 14, 77.

Submitted: September 12, 2017

Published online: December 6, 2017 